\title{
A Governance Mechanisms Framework for Multisourcing in Business Groups
}

\author{
Thomas Ph. Herz, University of St. Gallen, Switzerland \\ Florian Hamel, University of St. Gallen, Switzerland \\ Falk Uebernickel, University of St. Gallen, Switzerland \\ Walter Brenner, University of St. Gallen, Switzerland
}

\begin{abstract}
Many large corporations are adopting multisourcing strategies. Multisourcing is described as the blending of services from multiple company-internal and external suppliers in the pursuit of business goals. To date, governance-related aspects in terms of multisourcing have been scarcely covered in the academic literature. With this research study, the authors examine how business groups utilize governance mechanisms in a multisourced IT environment. This article contributes to the body of knowledge in three ways. First, it describes established IT governance mechanisms; second, it presents insights into three real-life examples of IT governance mechanisms at leading international insurance companies; and third, it extends current literature toward multisourcing in a group context by proposing and applying a framework of IT governance mechanisms targeting the different relationships of multisourcing in business groups. In addition, this research is useful for corporations facing similar challenges.
\end{abstract}

Keywords: $\quad$ Business Groups, Governance Mechanisms, International Insurance Companies, ITOutsourcing, Managing Relationships, Multisourcing

\section{INTRODUCTION}

Multisourcing has been identified by both practitioner-related and scholarly literature as an emerging key strategy in today`s IT outsourcing endeavors of many large corporations (e.g., Bapna, Barua, Mani, \& Mehra, 2010; Cohen \& Young, 2006; Janischowsky \& Schonenbach, 2009; Levina \& Su, 2008; Oshri, Kotlarsky,

DOI: $10.4018 /$ jitbag.2011070103
Rottman, \& Willcocks, 2009). Cohen and Young describe multisourcing as the blending of services from multiple company-internal and external suppliers (Cohen \& Young, 2006). The major part of current studies addresses dyadic IT outsourcing relationships; however, linear extensions of those are not sufficient to capture the details of multisourcing (Bapna et al., 2010).

Moreover, governance-related aspects in the context of implementing a sourcing decision (Dibbern, Goles, Hirschheim, \& Jayatilaka, 
2004) have scarcely been covered despite their great relevance (Busi \& McIvor, 2008; Clark, Zmud, \& McCray, 1995; Davis, 1996; Dibbern et al., 2004; Gottschalk \& Solli-Sæther, 2005; Klepper, 1995; McFarlan \& Nolan, 1995; Weimer \& Seuring, 2009; Willcocks \& Choi, 1995 ) and the extensive research that has been conducted in general on IT governance (e.g., De Haes \& Van Grembergen, 2009; Henderson \& Venkatraman, 1993; ITGI, 2007; Loh \& Venkatraman, 1992; Sambamurthy \& Zmud, 1999; Weill \& Ross, 2004). This study builds upon those findings and aims to extend current literature toward multisourcing in business groups.

Preliminary expert interviews with senior IT management consultants have indicated that governance aspects in multisourcing are of great practical relevance. Serving as an example, one interviewee stated:

In our clients' frequently multi-sourced IT function, governance is of high relevance, yet the clients struggle to identify the right levers to implement.

With this research study, we intend to broaden understanding of how business groups implement governance mechanisms in a multisourced IT environment. Therefore, we have defined one comprehensive research question:

\section{[RQ] How do business groups apply governance mechanisms in multisourcing?}

This question has been further specified into two detailed sub-research questions:

[RQ.1] What are relevant IT governance mechanisms based on the current body of knowledge?

[RQ.2] Which mechanisms could a multisourcing governance framework in a business group encompass?

To answer these research questions, we conducted both a qualitative in-depth single case study and a qualitative multiple case study to investigate multisourcing relationships at leading international insurance groups providing primary insurance, re-insurance, banking and asset management services. We have chosen this industry because financial services providers such as banks and insurance companies are in the forefront of outsourcing and offshoring both IT and business processes (Levina \& Su, 2008).

This article aims to contribute to research on IT outsourcing in general and IT governance mechanisms in a multisourcing context specifically, and is structured as follows. Section 2 outlines the research methodology. Section 3 provides an overview of fundamental terms and related research. Section 4 considers the single case of a leading insurance group. Section 5 reveals the main case study findings and discusses our proposal toward a framework of IT governance mechanisms. In Section 6 we apply the proposed framework in a multiple case study in the insurance industry, and in Section 7 we highlight the lessons learned before we conclude in Section 8.

\section{RESEARCH METHODOLOGY}

We have chosen a five-step research approach. In order to validate our research questions with regard to relevance, we interviewed sourcing experts. Furthermore, we analyzed the current body of knowledge and conducted an in-depth single case study in order to investigate a real-life example of governance mechanisms in multisourcing. Based on those findings, we synthesized and proposed a framework of governance mechanisms targeting the different relationships of multisourcing in a business group. The framework has been evaluated with experts. Finally, we conducted a multiple case study in the insurance industry in order to apply and further verify the governance mechanisms framework.

\subsection{Expert Interviews}

In order to manifest the relevance of the research questions, we conducted expert interviews. We chose three senior experts from management 
Table 1. Expert interviews

\begin{tabular}{|c|c|c|}
\hline Expert & Company & Background \\
\hline 1 & Management consultant A & IT governance, IT sourcing, IT performance management \\
\hline 2 & Management consultant B & IT strategy, IT organization, IT sourcing, IT shared service centers \\
\hline 3 & Management consultant C & IT strategy, IT governance, IT sourcing (especially offshoring) \\
\hline
\end{tabular}

consulting firms based on their exceptional experience in dealing with multisourcing cases (Table 1).

Each interview was conducted in a 30-minute to one-hour period. The interviews were semi-structured and all were transcribed (Yin, 2003).

\subsection{Literature Review}

We conducted a thorough literature review, according to Vom Brocke et al. (2009), of IT governance in general and governance mechanisms in particular, in order to provide an overview of the current body of knowledge and to share understanding of basic terms (Zorn \& Campbell, 2006). By focusing our research study on multisourcing, we could also investigate governance mechanisms that are utilized in IT outsourcing relationships (Section 3).

\subsection{Single Case Study - In-Depth Insights into Governance Mechanisms}

A thorough single case study (Yin, 2003) constituted the basis for developing a governance mechanisms framework. Its purpose was to analyze the global multisourcing approach of Insurer A and to identify the governance mechanisms applied. In general, case studies allow for a facilitation and deeper understanding of complex phenomena. Consequently, they are beneficial research designs for qualitative research in IS (Benbasat, Goldstein, \& Mead, 1987; Palvia, Pinjani, \& Sibley, 2007).

The leading insurance group, in the following Insurer A, is advantageous as a single case because it is characterized by a high level of complexity, an enormous number of business entities in the context of a business group organizational model, and an intense multisourcing approach. These features are considered rare, thus justifying the selection of Insurer A for a single case (Yin, 2003).

Additional rigor is gained through access to previously inaccessible key documents and a close relationship between the researchers and the key stakeholders at Insurer A (GoldenBiddle \& Locke, 2007; Yin, 2003).

Moreover, according to Yin(2003), a single case study adds value if it is used to explore a previously unresearched field. Yin acknowledges that a complete and detailed description of a scarce phenomenon is a contribution to knowledge itself.

In order to meet the requirements identified by Yin (2003), detailed information about the global multisourcing approach of Insurer A was gathered through multiple interviews with its representatives and external suppliers, as illustrated in Table 2.

The data collection process was conducted over a four-month period in spring 2010. Each interview lasted one to two hours. The interview guidelines were based on the expert interviews conducted before the single case study and covered the multisourcing approach chosen with a special emphasis on governance mechanisms.

In addition to the semi-structured interviews, the researchers had access to the following: documentation of multisourcing approach, contracts, transition documents, board reports, and performance and supplier relationship management reports. 
Table 2. Case study interviews with Insurer A

\begin{tabular}{|c|c|c|}
\hline ID & Role / Affiliation & Responsibilities \\
\hline 1 & Multisourcing program manager at Insurer A & Overall program responsibility \\
\hline 2 & Multisourcing project manager at Insurer A & Project responsibility \\
\hline 3 & Transition manager at Insurer A & $\begin{array}{c}\text { Transition to business entities and support of local } \\
\text { implementation }\end{array}$ \\
\hline 4 & Supplier relationship manager at Insurer A & $\begin{array}{c}\text { Supplier relationship management, contract man- } \\
\text { agement and deals tracking }\end{array}$ \\
\hline 5 & Multisourcing controller at Insurer A & Financial and multisourcing controlling \\
\hline 6 & Multisourcing manager of large business & $\begin{array}{c}\text { Implementation of multisourcing at business entity } \\
\text { entity at Insurer A }\end{array}$ \\
\hline 7 & Relationship manager at external supplier A & Management of relationship with Insurer A \\
\hline 9 & Relationship manager at external supplier B & Management of relationship with Insurer A \\
\hline
\end{tabular}

\subsection{Analysis and Evaluation}

The process of data collection and analysis conforms with guidelines suggested by Glaser and Strauss (1967) and Patton (2002). Thus, theory construction resulted simultaneously from interview guidelines based on previous interviews (theoretical sampling) and continuous interviews until theoretical saturation was reached. For data analysis, we applied open coding as suggested by Corbin and Strauss (1990). All interviews were transcribed. To verify the transcripts, we subsequently challenged the transcripts in an iterative process with the interview partners. The additional internal documents of Insurer A were also examined and the data were triangulated with the findings of the single case study (Denzin, 2009; Patton, 2002).

In order to validate the findings from the single case study with Insurer A, we had the opportunity to present and discuss our generalized model with sourcing practitioners and IT management consultants during an expert workshop. Additionally, we carried out three follow-up expert discussions in the fall of 2010.

\subsection{Multiple Case Study - Application of Governance Mechanisms Framework}

After evaluating the framework we conducted a multiple case study with leading international insurance companies according to Yin (2003) and Eisenhardt (1989). We interviewed four insurance companies. One of them is acknowledged as one of the world's leading re-insurance companies. The other three were primary insurance companies and were amongst the top five insurance companies based on their operating profit in 2010.

The data collection process was conducted over a two-month period in 2011. Each interview lasted two to three hours. The focus of the interviews was mainly on governance mechanisms applied in multisourcing and the relation to the chosen multisourcing approach. We analyzed the cases and aimed to validate the applicability of the framework that we developed on the previous single case with Insurer A. The multiple case study derived two extreme cases of multisourcing that serve as an illustrative example in the course of this article (Table 3). 
Table 3. Multiple case study - information on two selected cases

\begin{tabular}{|c|c|c|}
\hline Case & Number of interviews & Role of interviewee \\
\hline Insurer B & 3 & CIO, senior sourcing governance manager \\
\hline Insurer C & 5 & CIO, sourcing executive \\
\hline
\end{tabular}

\section{THEORETICAL FOUNDATION AND RELATED RESEARCH}

For a field of research it is important to share understanding of basic terms. For this reason, Zorn and Campbell (2006) suggest defining key terms. Based on a literature review, we provide an introduction to multisourcing in a group context and give an overview of governance mechanisms discussed in current literature.

\subsection{Multisourcing in a Group Context}

The definition of the multisourcing concept, according to Cohen and Young (2006), comprises the parallel utilization of services from multiple company-internal (such as in-house staff or shared service centers) and external suppliers. The increasing importance of multisourcing strategies in a dynamic and global business environment is associated with the corporate prioritization of cost efficiency, flexibility, and quality (Bapna et al., 2010; Hakkenberg, Himmelreich, Ketterer, \& Woelders, 2011; Levina \& Su, 2008; Su \& Levina, 2011). The application of multisourcing strategies sets high prerequisites for managerial capabilities and extensive requirements in terms of governance of multisourcing relationships (Levina \& Su, 2008). Also, multisourcing may impose adaptations to the corporation's operational model (Bapna et al., 2010; Cohen \& Young, 2006; Jayatilaka, 2006; Levina \& Su, 2008).

Many international corporations are adopting multisourcing, such as large business groups (Da Rold \& Karamouzis, 2009). For the term business group a wide range of definitions exist (Granovetter, 1994; Guillén, 2000; Leff, 1978;
Nicodano, 1998). For our research study, we apply Granovetter's (1994) definition of business groups as "sets of legally separate firms bound together in persistent formal and/or informal ways". This also encompasses management holdings in which a parent company "confines itself to strategy and finance, and owns operational subsidiaries that are legally separate" (Granovetter, 1994). Furthermore, a business group is characterized by a systematic delegation of duties between the group center and the business entities (BE). While the extent to which the group center has vertical control over the business entities in terms of ownership and governance may vary, it is associated with a minimum of common administrative, financial, and managerial coordination (Granovetter, 1994). Figure 1 illustrates the concept of a business group.

Frequently, IT governance in business groups is characterized by a federal model (e.g., Hodgkinson, 1996; Sambamurthy \& Zmud, 1999; Weill, 2004). Weill defines this model "as coordinated decision making involving both a center and its business units" (Weill, 2004), which is in line with the definition of Sambamurthy and Zmud (1999) that emphasizes that both corporate IS (group center) and business entities assume authority for different IS functions. Moreover, Handy (1992) identifies the need for multi-level or at least two-level responsibility and accountability in business groups. In this context, the group center "provides group-wide IT services and exerts some degree of central leadership and control of IT activities" (Hodgkinson, 1996).

Hitherto, IT outsourcing research was mainly concerned with dyadic relationships. Due to multiple company-internal and ex- 
Figure 1. Concept of business groups (adapted from Janssen \& Joha, 2006)

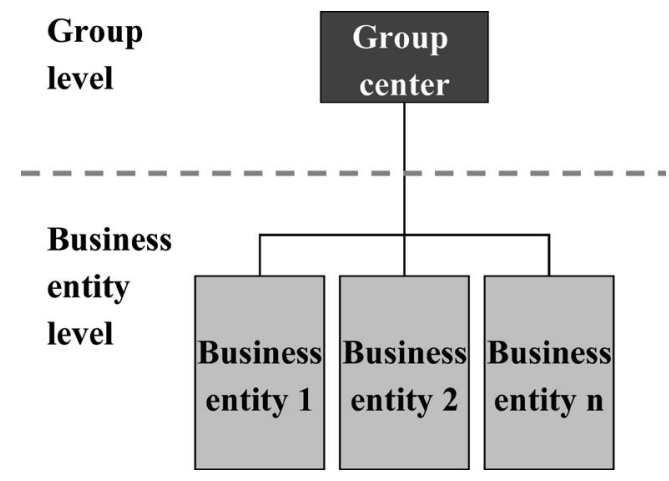

ternal suppliers of services, multisourcing itself increases complexity on the supply side. However, the organizational structure of a business group adds further complexity to the outsourcing relationship on the demand side because it requires the distribution of the sourcing activities between the group center and the business entities.

\subsection{Governance Mechanisms}

Van Grembergen and De Haes (2009) define $I T$ governance (enterprise governance of IT) as an "integral part of corporate governance", which "addresses the definition and implementation of processes, structures and relational mechanisms in the organization that enable both business and IT people to execute their responsibilities in support of business/IT alignment and the creation of business value from IT-enabled business investments". In this context, IT governance mechanisms are used to deploy IT governance in organizations (Peterson, 2004) and are used by IT managers on a daily basis (Weill \& Ross, 2005). According to Peterson (2004), there exist three types of IT governance mechanisms:

- Structures: "structural (formal) devices and mechanisms for connecting and enabling horizontal, or liaison, contacts between business and IT management (decision-making) functions".
- Processes: "formalization and institutionalization of strategic IT decision making or IT monitoring procedures".

- Relational mechanisms: "the active participation of, and collaborative relationship among, corporate executives, IT management, and business management".

Weill and Ross (2005) analogously define three types of governance mechanisms: decision-making structures, alignment processes, and formal communications.

In IT outsourcing, governance aspects have recently become of high relevance to practitioners and of scientific interest to researchers (e.g., Busi \& McIvor, 2008; Clark et al., 1995; Davis, 1996; Gottschalk \& Solli-Sæther, 2005; Klepper, 1995; Leimeister, 2010; McFarlan \& Nolan, 1995). Clark et al. (1995) state that "the truly critical success factors associated with successful outsourcing are those associated with vendor governance". In this respect, Behrens (2006) proposes four types of governance mechanisms that are relevant for IT outsourcing: contracts, processes, structural liaison devices, and relational norms.

All three definitions of governance mechanism types have in common processes, structures, and relational mechanisms as distinctive attributes. While also applying governance mechanisms to an external supplier in the context of IT outsourcing relationships, Behrens 
Table 4. Overview of governance mechanisms (based on key minimum baseline of De Haes \& Van Grembergen, 2009, and extended by Behrens, 2006)

\begin{tabular}{|c|c|}
\hline Type & Governance mechanisms \\
\hline Contracts & - Contractual agreements with suppliers \\
\hline Structures & $\begin{array}{l}\text { - IT steering committee } \\
\text { - IT project steering committee } \\
\text { - CIO reporting to } \mathrm{CEO} \text { and/or } \mathrm{COO}\end{array}$ \\
\hline Processes & $\begin{array}{l}\text { - Portfolio management (incl. business case, etc.) } \\
\text { - IT budget control and reporting } \\
\text { - Project governance/management methodologies }\end{array}$ \\
\hline Relational mechanisms & - IT leadership \\
\hline
\end{tabular}

(2006) adds the contract as a supplementary and distinct type of mechanism. This is supported by Currie and Willcocks (1998) and Cross (1995), who claim that contracts are of great importance in multisourcing.

Many researchers list concrete examples of governance mechanisms (e.g., Agarwal \& Sambamurthy, 2002; De Haes \& Van Grembergen, 2006; Luftman \& Brier, 1999; Peterson, 2004; Rau, 2004; Weill \& Ross, 2004). However, De Haes and Van Grembergen (2009) provide a summary of governance mechanisms and suggest a certain set of relevant ones. Table 4 gives an overview of the key minimum baseline $(K M B)$ for governance mechanisms based on De Haes and Van Grembergen (2009) and extends this list to outsourcing by adding the mechanism type contracts, as suggested by Behrens (2006).

The $K M B$ is a subset of a comprehensive, validated list $(C V L)$ of different governance mechanisms encompassing twelve mechanisms for structures, eleven for processes, and ten for relational mechanisms. This list has been identified from an intense literature review and condensed to a key minimum baseline concluding from extreme case research by De Haes and Van Grembergen (2009).

\section{SINGLE CASE DESCRIPTION - INSURER A}

Insurer A is one of the world's leading insurance groups offering primary insurance, banking and asset management services. It can best be described as a multinational business group with a group center and numerous legally independent business entities. The group center (holding organization) does not assume any operational responsibility.

The IT function of Insurer A is characterized by a decentralized approach with both a group chief information officer (GCIO) and local CIOs at business entities along with a federal model as regards IT governance. This is, for example, reflected in an IT committee as a decision making entity, which is headed by the GCIO and encompasses local CIOs of the main business entities.

In 2008, Insurer A implemented global multisourcing in the IT function. For this purpose, the previously largely unconsolidated supplier base was reduced to a few preferred external suppliers with strong offshore capabilities. The contractual framework for the selected suppliers with whom Insurer A entered into a strategic relationship consisted of a three-layered approach: [C.1] the multisourcing master service agreement (MMSA) at group level; [C.2] the multisourcing business entity specific service agreement $(M B S A)$ at business entity level; and [C.3] the multisourcing project specific service agreement (MPSA) at project level.

The development of the multisourcing concept at Insurer A was led by a multisourcing team at the group center with the support of some business entities and was rolled out in several phases at business entity level. The busi- 
ness entities' CIOs - supported by the transition managers from the central multisourcing team at the group center - were responsible for the implementation of the multisourcing concept at the globally dispersed business entities. Due to the federal governance model in the IT function, the central multisourcing team had no authority to force local CIOs to implement and utilize the developed multisourcing approach. For this reason, governance mechanisms were an important lever to support the implementation and utilization of the multisourcing concept within the business group and to steer the preferred external suppliers.

\section{SINGLE CASE ANALYSIS AND DISCUSSION - INSURER A}

Throughout our interviews at Insurer A, we encountered three major relationships of multisourcing in a group context and respective governance mechanisms that are utilized in each relationship. In the following, we describe these relationships and the particular governance mechanisms and propose - based on current literature and the in-depth single case study - a multisourcing governance mechanisms framework.

\subsection{Relevant Relationships when Applying Multisourcing in a Group Context}

We detected three major relationships which occur when a business group applies multisourcing (Figure 2):

- [R.1] Internal relationship between the group center and the individual business entities.

- [R.2] External relationship between the group center and the individual preferred external suppliers.

- [R.3] External relationship between the individual business entities and the individual preferred external suppliers.
Relationships [R.1] and [R.2] are characterized by a 1:n relationship (one-to-many) between the single group center and the various internal business entities and the various external preferred suppliers respectively. In comparison, relationship [R.3] between the individual business entities and the numerous preferred external suppliers can be characterized as a m:n relationship (many-to-many).

Relationship [R.1] represents the companyinternal governance model of a business group between the group center and the business entities. The relationships [R.2] and [R.3] represent the company-external or vendor governance (Clark et al., 1995). Thereby, [R.2] represents a strategic layer between the group center and the individual preferred external suppliers covering predominantly framework agreements as well as the strategic monitoring and steering of the suppliers. [R.3] represents an operative layer between the individual business entities and the preferred external suppliers. It principally covers individual contracts on business entity level and project level as well as the operational monitoring and steering in terms of service delivery.

\subsection{Governance Mechanisms Utilized in a Multisourced Environment and Proposition of a Framework}

Further, we identified several governance mechanisms that are utilized in multisourcing at a business group.

The analysis indicates that all governance mechanisms suggested in the KMB of De Haes and Van Grembergen (2009) can be identified in the single case study. This in turn validates the relevance of the stated governance mechanisms also for multisourcing in business groups. Four governance mechanisms that we identified are not listed in the KMB. However, they can be found in the CVL of twenty-three governance mechanisms identified by De Haes and Van Grembergen (2009). Only the contracts are not explicitly listed; however, the CVL encom- 
Figure 2. Relationships of multisourcing in a group context

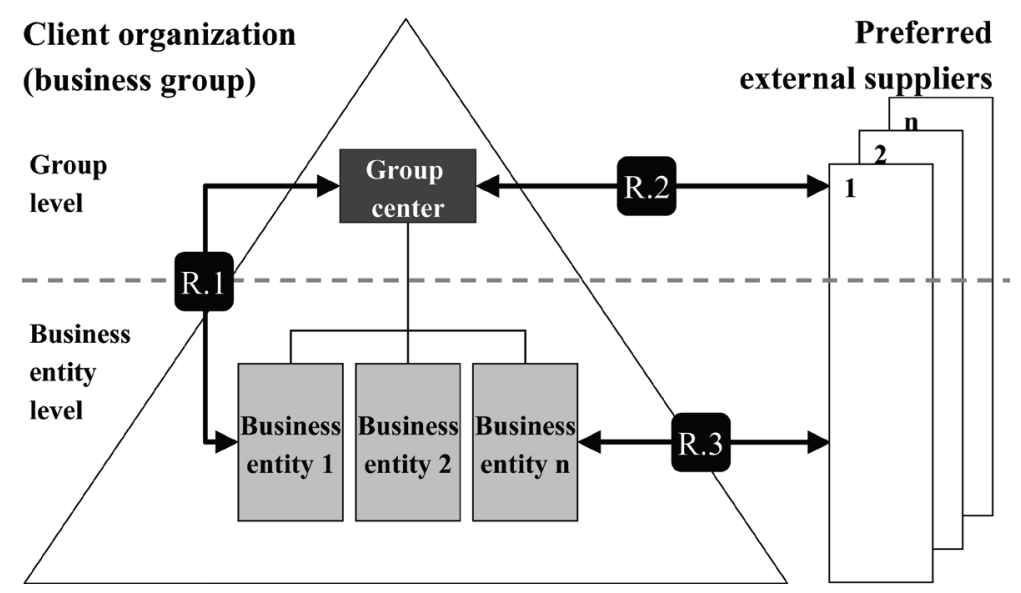

passes service level agreements (SLAs) listed as an IT governance process.

Nevertheless, we suggest contracts as a distinct attribute on the same level as structures, processes and relational mechanisms based on their importance in IT outsourcing relationships. Furthermore, we propose different types of contractual agreements. Contracts on project level usually encompass definite SLAs, whereas a framework agreement on group level covers a standard process model of collaboration in the context of a strategic relationship.

While contracts are mainly the outcome of negotiations with suppliers, we suggest leveraging them as governance mechanisms and thereby support Gellings (2007). In particular, it is important to emphasize the different contractual agreements within the group and their different objectives. At group level, contracts tend to be strategic and encompass relationship and collaboration-related aspects between the client organization and the external suppliers. Contracts on the business entity level adapt the framework agreement to local specialties such as local laws. In order to steer the service delivery, distinct SLAs are defined at the project level. Current governance literature is confined to SLAs and we intend to improve this shortcoming in the context of multisourcing in business groups.

Our findings, based on current literature and single case analysis, indicate two basic dimensions of multisourcing governance mechanisms in a group context:

- Company-internal mechanisms are applied in relationship [R.1] of the group center and the business entities.

- Supplier-related mechanisms are applied to the preferred external suppliers on a strategic layer [R.2] and on an operational layer [R.3].

In order to derive a framework of IT governance mechanisms that targets the different relationships of multisourcing in business groups, we map the identified governance mechanisms to the three relationships. We further validate the observed governance mechanisms with current literature and indicate if those are covered in the CVL and/or the KMB. Since the KMB is a subset of CVL, we state "both" in relevant cases. Table 5 illustrates the proposed framework that is based on in-depth case study research and literature. 
Table 5. Mapping of governance mechanisms to multisourcing relationships in order to derive a multisourcing governance mechanisms framework

\begin{tabular}{|c|c|c|c|c|}
\hline Type & $\begin{array}{c}\text { Multisourcing Governance } \\
\text { Mechanisms }\end{array}$ & Dimension & Relationship & Covered by \\
\hline Contracts & $\begin{array}{l}\text { Contractual agreements on: } \\
\text { - Group level } \\
\text { - Business entity level } \\
\text { - Project level }\end{array}$ & $\begin{array}{l}\text { - Supplier-related } \\
\text { - Supplier-related } \\
\text { - Supplier-related }\end{array}$ & $\begin{array}{l}-[\text { R.2 }] \\
-[\text { R.3] } \\
-[\text { R.3] }\end{array}$ & $\begin{array}{l}\text { None, yet } \\
\text { CVL covers } \\
\text { SLAs }\end{array}$ \\
\hline Structures & $\begin{array}{l}\text { - IT steering committee } \\
\text { - Multisourcing project committee } \\
\text { - General and multisourcing specific } \\
\text { reporting structures }\end{array}$ & $\begin{array}{l}\text { - Company-internal } \\
\text { - Supplier-related } \\
\text { - Company-internal }\end{array}$ & $\begin{array}{l}-[\text { R.1] } \\
-[\text { R.2], [R.3] } \\
-[\text { R.1] }\end{array}$ & $\begin{array}{l}- \text { Both } \\
- \text { Both } \\
- \text { Both }\end{array}$ \\
\hline Processes & $\begin{array}{l}\text { - Performance measurement } \\
\text { - Customer satisfaction survey } \\
\text { - Sourcing portfolio management } \\
\text { - Sourcing planning } \\
\text { - Group/business entity specific busi- } \\
\text { ness case } \\
\text { - Sourcing mgmt. methodologies } \\
\text { - Multisourcing deals tracking } \\
\text { - Process optimization } \\
\text { - Multisourcing control and reporting } \\
\text { - Strategic level } \\
\text { - Operational level } \\
\text { - Benefits management and reporting }\end{array}$ & $\begin{array}{l}\text { - Supplier-related } \\
\text { - Company-internal } \\
\text { - Company-internal } \\
\text { - Supplier-related } \\
\text { - Company-internal } \\
\text { - Supplier-related } \\
\text { - Supplier-related } \\
\text { - Company-internal }\end{array}$ & $\begin{array}{l}-[\text { R.2 }],[\text { R.3 }] \\
-[\text { R.1] } \\
-[\text { R.1 }] \\
-[\text { R.2] } \\
-[\text { R.1] } \\
-[\text { R.2 }] \\
-[\text { R.3] } \\
-[\text { R.1 }]\end{array}$ & $\begin{array}{l}- \text { CVL } \\
- \text { Both } \\
- \text { Both } \\
\text { - Both } \\
\text { - Both } \\
\text { - Both } \\
\text { - Both } \\
\text { - CVL }\end{array}$ \\
\hline $\begin{array}{l}\text { Relational } \\
\text { mechanisms }\end{array}$ & $\begin{array}{l}\text { - Knowledge management } \\
\text { - Internal knowledge mgmt. } \\
\text { - Transition to supplier } \\
\text { - Informal supplier meetings } \\
\text { - Multisourcing leadership }\end{array}$ & $\begin{array}{l}\text { - Company-internal } \\
\text { - Supplier-related } \\
\text { - Supplier-related } \\
\text { - Company-internal }\end{array}$ & $\begin{array}{l}-[\text { R.1 }] \\
-[\text { R.3] } \\
-[\text { R.2], [R.3] } \\
-[\text { R.1] }\end{array}$ & $\begin{array}{l}-\mathrm{CVL} \\
-\mathrm{CVL} \\
-\mathrm{CVL} \\
- \text { Both }\end{array}$ \\
\hline
\end{tabular}

During the validation with sourcing practitioners and IT management consultants, we had the opportunity to specify our framework in terms of distinct mechanisms and relationship structure as well as the three different layers of contractual agreements. In our governance mechanisms framework, which is principally dedicated to multisourcing, we propose at least one governance mechanism in each of the four types that is related to the supplier and covers the relationship [R.2] or [R.3] or both.

Thereby, we extend the current literature on IT governance mechanisms that focus on the company-internal dimension relationship [R.1] only. In addition, we propose particular multisourcing governance mechanisms targeting the specifics of a business group, while adopting those of the KMB.

\section{APPLICATION OF PROPOSED FRAMEWORK TO PRACTICE}

In the following we describe the application of the proposed multisourcing governance mechanisms framework during a multiple case study research with leading insurance companies. Throughout the analysis we have encountered two extreme examples of multisourcing. These are illustrated in exemplary form in this article.

\subsection{Description of Insurer B and C}

Insurer B is acknowledged to be one of the world's leading re-insurance companies and serves business clients in more than 160 countries. The organizational setup is a business 
group structure and the specifics of re-insurance are to be considered as the CIO stated:

The nature of the re-insurance business is different from primary insurance since you balance risks on a global scale and serve just a few business clients. However, the complexity of data and number of applications is enormous.

In the IT function Insurer B is following a strictly centralized organizational model, and multisourcing with a limited number of strategic partners has been implemented over a ten year timeframe step-by-step.

Insurer $\mathrm{C}$ is a worldwide leading primary insurance company serving mainly private clients in more than 170 countries and claims to operate on a truly global basis as a globally integrated insurance group. In the IT function Insurer $\mathrm{C}$ follows a federal organizational model with respective governance. In terms of multisourcing, Insurer $\mathrm{C}$ has outsourced major parts of its infrastructure and the technical aspects such as coding and testing of application development in a big-bang to multiple global and local suppliers; meanwhile, functional aspects such as requirements' definition and user acceptance tests (UAT) are kept internally.

\subsection{Verification with Insurers B and C}

These examples indicate two extreme cases of multisourcing; however, we found interesting similarities between the two of them and the in-depth single case of Insurer A.

First, the interviewees in all cases emphasize the two dimensions of governance and its mechanisms in a multisourced environment (internal-related and supplier-related governance mechanisms) and distinguish between a strategic and an operational layer in terms of supplier-related governance (relationships [R.2] and [R.3]), thereby verifying our propositions. The CIO of Insurer B argues:

We have even implemented dedicated, organizationally separated roles taking care of, on the one hand, internal governance and, on the other, hand supplier governance.

Second, the contractual frameworks also encompass three levels as observed in the case of Insurer A. On a group level, a framework agreement defines overarching rules and collaboration procedures with the multiple external suppliers. On project level, concrete details about a service or a project are defined. In between the group and project levels, different approaches can be observed. Insurers $\mathrm{A}$ and $\mathrm{C}$ utilize business entity agreements to cover their federal organizational model and adapt the framework agreement to local laws and regulations. Insurer $\mathrm{B}$, being much more centralized, is not applying business entity-level agreements in any case, but applies this logic as well for selected, decentralized IT services.

Third, the proposed framework can also be applied in the case of Insurer B and Insurer C. The case study has verified that Insurer B and Insurer $\mathrm{C}$ apply governance mechanisms of all types - except contracts, since they are solely focused on the company-external relationships [R.2] and [R.3] - to cover all company-internal and supplier-related relationships: [R.1], [R.2] and [R.3]. Therefore, we can validate the applicability of the governance mechanism types (contracts, structures, processes, and relational mechanisms) to multisourcing and the specific relationships in a group context.

\section{LESSONS LEARNED}

During our research study with Insurers A, $\mathrm{B}$ and $\mathrm{C}$ we encountered a set of lessons that could be helpful for organizations acting in a multisourced environment.

Lesson 1: Utilize governance mechanisms to support the implementation of multisourcing. The study reveals that governance mechanisms are a lever to implement multisourcing in business groups. The identified examples and the derived framework might 
guide organizations by defining the right set of mechanisms.

Lesson 2: Use a two-dimensional approach to governance mechanisms. In order to cover all the specific relationships of multisourcing in business groups, our findings suggest using both company-internal and supplier-related governance mechanisms.

Lesson 3: Contractual agreements are identified as an important supplier-related governance mechanism. The study recommends utilizing contractual agreements in addition to other governance mechanisms. In particular, it recommends cascading contractual agreements covering group, business entity, and project level. This approach allows for each business entity to utilize the master service agreement and to adopt standardized and pre-negotiated agreements on the business entity and project levels to individual needs.

Lesson 4: Define governance mechanisms before entering into negotiations. Since multisourcing might require some organizations to adapt their operational model and sets high prerequisites for managerial capabilities, the study proposes defining governance mechanisms before entering into negotiations with potential suppliers. This timely definition ensures that governance mechanisms such as KPIs or SLAs are already discussed and agreed on during the request-for-information (RFI) or request-for-proposal (RFP) phases. Integration after contract closure is rarely beneficial for the client organization.

Lesson 5: Central multisourcing instances are advantageous. The research study further exposes that a central multisourcing instance is helpful. This instance (one role or a team, e.g., joint multisourcing project management office) can coordinate the multiple suppliers and the various business entities and allows for standardization and economies of scale.

Lesson 6: Multisourcing is not procurement. All interviewees were very clear on this aspect and one interviewee mentioned.

\section{Multisourcing is not a sole procurement activity; it is much more than this.}

While procurement is only a small part of multisourcing (e.g., negotiating prices based on bundling and scale effects), multisourcing encompasses much change management and collaboration with internal and external suppliers in the pursuit of business goals.

\section{CONCLUSION}

With this study we provided an in-depth single case study of a leading worldwide insurance company and its progression toward multisourcing as well as findings from a multiple case study in the insurance industry. Based on a broad literature review, a detailed single case analysis and a verifying multiple case study analysis, we extended current work on this area and aimed to answer two sub-research questions that supported our overall research question: How do business groups apply governance mechanisms in multisourcing?

By answering this question, we aimed to contribute to the body of knowledge on IT outsourcing in general and IT governance mechanisms in particular, by extending the current literature to include multisourcing in a group context. For this purpose, we proposed a framework of governance mechanisms that specifically targets the different relationships of multisourcing in business groups. In order to derive a framework, we conducted an in-depth literature review on multisourcing and business groups and built upon existing research on IT governance mechanisms. In a detailed single case analysis of Insurer A, we extracted multisourcing governance mechanisms and mapped them to current literature. This in turn built the basis for our proposed multisourcing governance mechanisms framework that added a supplier-related dimension and corresponding mechanisms. The applicability of the framework has been verified in the course of a multiple case study with Insurer B and Insurer C. Moreover, the lessons learned section of this 
article should be useful for corporations facing similar situations.

Overall, we discerned that current literature on IT governance mechanisms can for the most part be applied to multisourcing. Our study indicated that the most important governance mechanisms suggested in the literature are also utilized by business groups generally and in a multisourcing context in particular. This validates the relevance of the stated governance mechanisms in literature. However, we suggest supplementing the current literature with the mechanism type contracts and introducing governance mechanisms that cover the supplierrelated relationship.

However, this study also has some limitations. One limitation is that we derived the framework from a single case. Therefore we conducted a subsequent multiple case study to verify the applicability of the framework and support the generalized character of the model.

A further limitation is that we limited our research to the insurance industry. The authors suggest expanding it to include different industries and to reflect the findings of this study.

\section{ACKNOWLEDGMENT}

An earlier version of this article has been presented and published at HICSS-45. The authors would like to thank the anonymous reviewers for the valuable feedback.

\section{REFERENCES}

Agarwal, R., \& Sambamurthy, V. (2002). Principles and models for organizing the IT function. MIS Quarterly Executive, 1(1), 1-16.

Bapna, R., Barua, A., Mani, D., \& Mehra, A. (2010). Cooperation, coordination, and governance in multisourcing: An agenda for analytical and empirical research. Information Systems Research, 21(4), 785-795. doi:10.1287/isre.1100.0328

Behrens, S. (2006). Governance and information systems outsourcing success: A contingency perspective. Paper presented at the Multikonferenz Wirtschaftsinformatik, Passau, Germany.
Benbasat, I., Goldstein, D. K., \& Mead, M. (1987). The case research strategy in studies of information systems. Management Information Systems Quarterly, 11(3), 369-386. doi:10.2307/248684

Busi, M., \& McIvor, R. (2008). Setting the outsourcing research agenda: the top-10 most urgent outsourcing areas. Strategic Outsourcing: An International Journal of Information Management, 1(3), 185-197. doi:10.1108/17538290810915263

Clark, T. D., Zmud, R. W., \& McCray, G. E. (1995). The outsourcing of information services: transforming the nature of business in the information industry. Journal of Information Technology, 10(4), 221-237. doi:10.1057/jit.1995.26

Cohen, L. R., \& Young, A. (2006). Multisourcing: Moving beyond outsourcing to achieve growth and agility. Boston, MA: Harvard Business School Press.

Corbin, J. M., \& Strauss, A. L. (1990). Grounded theory research: Procedures, canons and evaluative criteria. Qualitative Sociology, 13(1), 3-21. doi:10.1007/BF00988593

Cross, J. (1995). IT outsourcing: British Petroleum's competitive approach. Harvard Business Review, 73(3), 94-102.

Currie, W. L., \& Willcocks, L. P. (1998). Analysing four types of IT sourcing decisions in the context of scale, client/supplier interdependency and risk mitigation. Information Systems Journal, 8(2), 119-143. doi:10.1046/j.1365-2575.1998.00030.x

Da Rold, C., \& Karamouzis, F. (2009). Case study: Zurich Financial Services Group delivers business value through its multisourcing strategy. Stamford, CT: Gartner Research.

Davis, K. J. (1996). IT outsourcing relationships: An exploratory study of interorganizational control mechanisms. Boston, MA: Harvard University.

De Haes, S., \& Van Grembergen, W. (2006). Information technology governance best practices in Belgian organisations. In Proceedings of the 39th Annual Hawaii International Conference on System Sciences.

De Haes, S., \& Van Grembergen, W. (2009). An exploratory study into IT governance implementations and its impact on business/IT alignment. Information Systems Management, 26(2), 123-137. doi:10.1080/10580530902794786

Denzin, N. (2009). The research act: A theoretical introduction to sociological methods. Piscataway, NJ: Transaction. 
Dibbern, J., Goles, T., Hirschheim, R., \& Jayatilaka, B. (2004). Information systems outsourcing: A survey and analysis of the literature. The Data Base for Advances in Information Systems, 35(4), 6-102.

Eisenhardt, K. M. (1989). Building theories from case-study research. Academy of Management Review, 14(4), 532-550.

Gellings, C. (2007). Outsourcing relationships: The contract as IT governance tool. In Proceedings of the 40th Annual Hawaii International Conference on System Sciences, Waikoloa, HI.

Glaser, B. G., \& Strauss, A. L. (1967). The discovery of grounded theory: Strategies for qualitative research. Chicago, IL: Aldine.

Golden-Biddle, K., \& Locke, K. (2007). Composing qualitative research. Thousand Oaks, CA: Sage.

Gottschalk, P., \& Solli-Sæther, H. (2005). Critical success factors from IT outsourcing theories: an empirical study. Industrial Management \& Data Systems, 105(6), 685-702. doi:10.1108/02635570510606941

Granovetter, M. S. (1994). Business groups and social organization. In Smelser, N. J., \& Swedberg, R. (Eds.), The handbook of economic sociology. Princeton, NJ: Princeton University Press.

Guillén, M. F. (2000). Business groups in emerging economies: A resource-based view. Academy of Management Journal, 43(3), 362-380. doi: $10.2307 / 1556400$

Hakkenberg, M., Himmelreich, H., Ketterer, H., \& Woelders, F. (2011). Shared KPIs in multivendor IT outsourcing. In BCG (Ed.), IT advantage (pp. 16-19). Boston, MA: The Boston Consulting Group.

Handy, C. (1992). Balancing corporate power: A new federalist paper. Harvard Business Review, 70(6), 59-72.

Henderson, J. C., \& Venkatraman, N. (1993). Strategic alignment: Leveraging information technology for transforming organizations. IBMSystems Journal, 32(1), 472-485. doi:10.1147/sj.382.0472

Hodgkinson, S. L. (1996). The role of the corporate IT function in the federal IT organization . In Earl, M. J. (Ed.), Information management: The organizational dimension (pp. 247-269). Oxford, UK: Oxford University Press.

ITGI. (2007). COBIT 4.1. Rolling Meadows, IL: IT Governance Institute.

Janischowsky, B., \& Schonenbach, R.(2009). Getting multisourcing right! (Vol. 2). London, UK: Sovereign.
Janssen, M., \& Joha,A. (2006). Motives for establishing shared service centers in public administration. International Journal of Information Management, 6(2), 102-115. doi:10.1016/j.ijinfomgt.2005.11.006

Jayatilaka, B. (2006). IT sourcing: A dynamic phenomenon: Forming an institutional theory perspective. In Hirschheim, R. A., Heinzl, A., \& Dibbern, J. (Eds.), Information systems outsourcing: enduring themes, new perspectives, and global challenges (2nd ed.). Heidelberg, Germany: Springer-Verlag.

Klepper, R. (1995). The management of partnering development in I/S outsourcing. Journal of Information Technology, 10(4), 249-258. doi:10.1057/ jit.1995.28

Leff, N. H. (1978). Industrial organization and entrepreneurship in the developing countries - Economic groups. Economic Development and Cultural Change, 26(4), 661-675. doi:10.1086/451052

Leimeister, S. (2010). IT outsourcing governance. Wiesbaden, Germany: Gabler Verlag. doi:10.1007/978-3-8349-6303-1

Levina, N., \& Su, N. (2008). Global multisourcing strategy: The emergence of a supplier portfolio in services offshoring. Decision Sciences, 39(3), 541-570. doi:10.1111/j.1540-5915.2008.00202.x

Loh, L., \& Venkatraman, N. (1992). Diffusion of information technology outsourcing: Influence sources and the Kodak Effect. Information Systems Research, 3(4), 334-359. doi:10.1287/isre.3.4.334

Luftman, J., \& Brier, T. (1999). Achieving and sustaining business-IT alignment. California Management Review, 42(1), 109-122.

McFarlan, F. W., \& Nolan, R. L. (1995). How to manage an IT outsourcing alliance. Sloan Management Review, 36(2), 9-23.

Nicodano, G. (1998). Corporate groups, dual-class shares and the value of voting rights. Journal of Banking \& Finance, 22(9), 1117-1137. doi:10.1016/ S0378-4266(98)00051-X

Oshri, I., Kotlarsky, J., Rottman, J. W., \& Willcocks, L. P. (2009). Global sourcing: recent trends and issues. Information Technology \& People, 22(3), 192-200. doi:10.1108/09593840910981400

Palvia, P., Pinjani, P., \& Sibley, E. H. (2007). A profile of information systems research published in Information \& Management. Information \& Management, 44(1), 1-11. doi:10.1016/j.im.2006.10.002

Patton, M.Q.(2002). Qualitative research and evaluation methods (3rd ed.). Thousand Oaks, CA: Sage. 
Peterson, R. R. (2004). Information strategies and tactics for information technology governance. In Van Grembergen, W.(Ed.), Strategies for information technology governance. Hershey, PA: Idea Group. doi:10.4018/9781599046549.ch013

Rau, K. G. (2004). Effective governance of IT: Design objectives, roles and relationships. Information Systems Management, 21(4), 35-43. doi:10.1201/1 078/44705.21.4.20040901/84185.4

Sambamurthy, V., \& Zmud, R. W. (1999). Arrangements for information technology governance: A theory of multiple contingencies. Management Information Systems Quarterly, 23(2), 261-291. doi: $10.2307 / 249754$

Su, N., \& Levina, N. (2011). Global multisourcing strategy: Integrating learning from manufacturing into IT service outsourcing. IEEE Transactions on Engineering Management, 58(4), 717-729. doi:10.1109/TEM.2010.2090733

Van Grembergen, W., \& De Haes, S. (2009). Enterprise governance of information technology-achieving strategic alignment and value. New York, NY: Springer. doi:10.1007/978-0-387-84882-2

vom Brocke, J., Simons, A., Niehaves, B., Riemer, K., Plattfaut, R., \& Cleven,A. (2009). Reconstructing the giant: On the importance of rigour in documenting the literature search process. Paper presented at the 17 th European Conference on Information Systems.
Weill, P. (2004). Don't just lead, govern: How topperforming firms govern IT. MIS Quarterly Executive, 8(1), 1-21.

Weill, P., \& Ross, J. W. (2004). IT governance: How top performers manage IT decision rights for superior results. Boston, MA: Harvard Business Press.

Weill, P., \& Ross, J. W. (2005). A matrixed approach to designing IT governance. MITSloan Management Review, 46(2), 25-34.

Weimer, G., \& Seuring, S. (2009). Performance measurement in business process outsourcing decisions: Insights from four case studies. Strategic Outsourcing: An International Journal, 2(3), 275-292. doi:10.1108/17538290911005171

Willcocks, L. P., \& Choi, C. J. (1995). Co-operative partnership and 'total' IT outsourcing: From contractual obligation to strategic alliance? European Management Journal, 13(1), 67-78. doi:10.1016/02632373(94)00059-G

Yin, R. K. (2003). Case study research: Design and methods. London, UK: Sage.

Zorn, T., \& Campbell, N. (2006). Improving the writing of literature reviews through a literature integration exercise. Business Communication Quarterly, 69(2), 172-183. doi:10.1177/1080569906287960 